Sun Liping, Zheng Dongwen. A study on the Causes of International Anti-Corruption Cooperation between China and Southeast Asian Countries Under the Belt and Road Initiative

Научная статья

УДК 327(510)(5-014)

DOI: $10.18101 / 2305-753 X-2021-1-25-35$

\title{
A STUDY ON THE CAUSES OF INTERNATIONAL ANTI-CORRUPTION COOPERATION BETWEEN CHINA AND SOUTHEAST ASIAN COUNTRIES UNDER THE BELT AND ROAD INITIATIVE
}

\author{
(C) Sun Liping \\ $\mathrm{PhD}$, Professor, \\ Jilin University \\ 2699, Qianjin Street, Changchun 130012, China \\ sunlp@jlu.edu.cn \\ (C) Zheng Dongwen \\ Master, \\ Jilin University \\ 2699, Qianjin Street, Changchun 130012, China \\ sunlp@jlu.edu.cn
}

\begin{abstract}
With the continuous expansion of China's outward direct investment in countries along the «Maritime Silk Road», the external environment faced by China's outward direct investment has become increasingly complex. The impact of corruption and government quality has become more prominent. From 2014 to 2019, the corruption index and institutional distance had a significant impact on China's outward direct investment in the ten ASEAN countries along the Maritime Silk Road and the quality of their governments. The complex situation presented by the cases of the ten ASEAN countries shows that it is difficult to fully analyze the relationship between government quality and direct investment by a single variable such as a corruption index or an institutional distance. It is necessary to introduce a comprehensive analysis of multiple factors, such as cultural distance, political stability, and bilateral relations. In view of this, China should strengthen the «Maritime Silk Road» construction corruption risk assessment, create a risk control mechanism and provide more regional public products that contribute to sustainable economic development and trade cooperation between countries along the «Maritime Silk Road».

Keywords: corruption perception index, institutional distance, foreign direct investment, Belt and Road Initiative

For citation

Sun Liping, Zheng Dongwen. A study on the Causes of International Anti-Corruption Cooperation between China and Southeast Asian Countries under the Belt and Road Initiative. Bulletin of Buryat State University. Humanities Research of Inner Asia. 2021; 1: $25-35$.
\end{abstract}

Corruption control is a key element to measure the governance level of a country's government, and it is also an important consideration that affects a country's overseas investment behavior. International organizations such as the United Nations and World Bank have repeatedly pointed out the importance of high-quality government for economic growth and social development in their work reports. Outward Foreign Direct Investment (OFDI) is an important way for a country to participate in the international division of labor and to optimize resource allocation. After Chinese President Xi Jinping 
proposed the establishment of the «21st Century Maritime Silk Road» initiative in 2013, investment and trade between China and ASEAN countries have grown rapidly. According to the statistics of the Ministry of Commerce of China, China's top 20 foreign direct investment flows in 2019 In the region, Singapore, Indonesia, Vietnam, Thailand, Laos, Malaysia and Cambodia and other ASEAN countries occupy 7 seats ${ }^{1}$.The widespread corruption in ASEAN countries has become an important factor affecting China's foreign investment. Academia has achieved certain academic results on the relationship between corruption and international capital flows. In addition to the issue of corruption, the rapid growth of China's investment in ASEAN countries also faces the impact of host country's government effectiveness, regulatory level, social and political stability, rule of law and other institutional factors closely related to corruption. This article intends to investigate on the basis of previous studies. The quality of government in Southeast Asian countries with corruption control as the core has an impact on China's foreign investment. It analyzes the deep motivations of China's anti-corruption international cooperation with Southeast Asian countries and makes corresponding recommendations accordingly.

The Selection of Government Quality Indicators and Theoretical Assumptions in Southeast Asian Countries

Generally speaking, corruption refers to the abuse of public office for personal gain. Specifically, it refers to the abuse of state rights by individuals with privileges to seek personal interests and disregard national interests. For a long time, the academic community has not yet reached an academic consensus on the evaluation of government quality, but government corruption is generally regarded as an important indicator. Some scholars also pointed out that the evaluation of government quality should mainly include three aspects, namely the rationality, efficiency and self-discipline of the government. Government corruption can be regarded as a manifestation of the selfdiscipline of the government ${ }^{2}$. From the perspective of government management and governance, the World Bank proposes that the quality of government should show the evaluation mechanism of a country's institutions, election supervision system, government effectiveness, executive power, and citizens' right to speak ${ }^{3}$.

In the research on the relationship between government quality and foreign direct investment, there are two more general assumptions.

Hypotheses A. There is a significant negative correlation between the degree of corruption in the host country and external direct investment.

Such articles emphasize that corruption increases the cost of foreign investors' investment in the host country, thereby reducing expected investment profits. Habib and Zurawicki used different data to verify that there is a significant negative correlation between the degree of government corruption in the host country and external direct investment ${ }^{4}$. Wang Yongqin and others pointed out that severe corruption punishments can limit corporate bribery and officials' corrupt behaviors, and protect the rights and

\footnotetext{
${ }^{1}$ China's foreign direct investment statistical bulletin in 2019. URL: https://www.askci.com/news/data/ hongguan/20200916//1047041217064.shtml (login time: 16.10.2020).

${ }^{2}$ Li Xiao. East Asian miracle and «strong government» // Economic Science Press. 1997. Pp. 48-63.

${ }^{3}$ Kaufmann D. Aggregating governance indicators // Policy Research Working Paper. World Bank. 1999. № 2195 .

${ }^{4}$ Habib M, Zurawicki L. Corruption and Foreign Direct Investment // Journal of International Business Studies. 2002. № 33(2). Pp. 291-307.
} 
Sun Liping, Zheng Dongwen. A study on the Causes of International Anti-Corruption Cooperation between China and Southeast Asian Countries Under the Belt and Road Initiative

interests of international investors ${ }^{1}$. Therefore, the more severe corruption punishments, the more conducive to international direct investment.

Hypotheses $B$. There is a significant negative correlation between the institutional distance of the host country and China's foreign direct investment.

This type of research emphasizes that institutional distance has a significant inhibitory effect on China's OFDI. Liu Xiaoguang and Yang Lianxing further affirmed the overall investment inhibitory effect of institutional distance based on micro-data at the enterprise level ${ }^{2}$. Institutional distance mainly affects OFDI through two paths: one is the direct effect of institutional distance itself. System differences between the home country and the host country will lead to investment risks to a certain extent, including systemic risks that are common to all investors and specific risks that are only targeted at home country investors ${ }^{3}$; second, the differences in bilateral systems will also bring investors Additional investment costs.

The above two common research hypotheses or assumptions are based on different theoretical perspectives and data model analysis. They mainly examine the cases of developed countries. China's direct foreign investment in the ten ASEAN countries has not yet been verified. There is also a close correlation between the two variables of corruption and institutional distance. This article attempts to use the The Worldwide Governance Indicators and the Corruption Perception Index as basic data to explore the relationship between host country government's corruption control, institutional distance, and China's direct foreign investment. Based on this, how to further strengthen the Chinese government's international anti-corruption cooperation, and with Chinese enterprises, how to avoid the political risks of investment, and put forward author's own suggestions.

Analysis of China's Investment in OFDI in Ten ASEAN Countries: a Quantitative Measurement Based on Corruption Control and Institutional Distance (2014-2019). The Relevance of Corruption Control in the ASEAN Countries and China's Direct Investment Abroad.

Among the many factors that affect China's direct investment in countries along the «Belt and Road», the host country's institutional factors are an important factor affecting OFDI's location selection. Corruption is an important indicator to measure the level of the system. Corruption reflects the extent to which the public power of the government is used for personal gain, including various forms of corruption and the extent to which the government is manipulated by elites and private interests.

Generally, academia regards the Global Corruption Perceptions Index as an important indicator to measure the degree of corruption in a country. It is a ranking of the Global Corruption Perceptions Index established by the non-governmental organization Transparency International. It reflects the perceptions of businessmen, scholars and risk analysts from all over the world on the corruption situation in many countries in the world. The score of each country ranges from 0 to 100. The higher the corruption

\footnotetext{
${ }^{1}$ Wang Yongqin, Du Julian, Wang Kai. Determinants of location choice of China's FDI: system, tax burden and resource endowment // Economic Research. 2014. Vol. 12. Pp. 126-142.

${ }^{2}$ Liu Xiaoguang, Yang Liankun. Bilateral political relations, institutional environment of host country and foreign direct investment // Financial Research. 2016. Vol. 12. Pp. 17-31.

${ }^{3}$ Zhang Qian, Li Fangfang, Cheng Baodong. Bilateral political relations, institutional environment of host country and location choice of OFDI in China // International Economic and trade exploration. 2019. Vol. 6. Pp. 89-103.
} 
index score, the lower the perceived corruption. In general, except for Singapore's corruption index, among the ten ASEAN countries, the corruption index has always been at the forefront, and most of the other countries are in the middle or low ranking.

Table 1

The Corruption Perceptions Index of the ASEAN Countries 2014-2019

\begin{tabular}{|c|c|c|c|c|c|c|}
\hline Countries/Year & 2014 & 2015 & 2016 & 2017 & 2018 & 2019 \\
\hline Brunei & N/A & N/A & 58 & 62 & 63 & 60 \\
\hline Cambodia & 21 & 21 & 21 & 21 & 20 & 20 \\
\hline Indonesia & 34 & 36 & 37 & 37 & 38 & 40 \\
\hline Laos & 25 & 25 & 30 & 29 & 29 & 29 \\
\hline Malaysia & 52 & 50 & 49 & 47 & 47 & 53 \\
\hline Myanmar & 21 & 22 & 28 & 30 & 29 & 29 \\
\hline Philippines & 38 & 35 & 35 & 34 & 36 & 34 \\
\hline Singapore & 84 & 85 & 84 & 84 & 85 & 85 \\
\hline Thailand & 38 & 38 & 35 & 37 & 36 & 36 \\
\hline Vietnam & 31 & 31 & 33 & 35 & 33 & 37 \\
\hline
\end{tabular}

The data comes from the official website of Transparency International. Brunei has missing data for the two years from 2014 to 2015. Corruption Perception Index CPI: https://www.transparency.de/cpi/, Updated time: August 8, 2020.

Since the Belt and Road Initiative was proposed in 2013, China's opening-up level has been further expanded and the pace of foreign direct investment has further increased. According to the 2019 Statistical Bulletin of China's Foreign Direct Investment.

In 2019, China's foreign direct investment was US\$136.91 billion, the flow of foreign direct investment continued to rank second in the world, and the stock of foreign direct investment remained the third globally. At the end of 2019, China's foreign direct investment stock reached US\$2.2 trillion, second to the United States (US\$7.7 trillion) and the Netherlands (US\$2.6 trillion). China has established more than 10,000 overseas companies in countries along the «Belt and Road». In 2019, it achieved direct investment of US $\$ 18.69$ billion, a year-on-year increase of $4.5 \%$, accounting for $13.7 \%$ of the same period; the year-end stock was US $\$ 179.47$ billion, accounting for $8.2 \%$ of the total stock. From 2013 to 2019, China's cumulative direct investment in countries along the route was US $\$ 117.31$ billion ${ }^{1}$.

\footnotetext{
${ }^{1}$ China's foreign direct investment statistical bulletin in 2019. URL: https://www.askci.com/news/data/ hongguan/20200916//1047041217064.shtml (login time: 16.10.2020).
} 
Sun Liping, Zheng Dongwen. A study on the Causes of International Anti-Corruption Cooperation between China and Southeast Asian Countries Under the Belt and Road Initiative

Table 2

2014-2019 China's direct investment flow statistics in ASEAN countries

\begin{tabular}{|c|c|c|c|c|c|c|}
\hline \multicolumn{9}{|c|}{} & \multicolumn{2}{c|}{ Unit:US\$10,000 } \\
\hline Country/Year & 2014 & 2015 & 2016 & 2017 & 2018 & 2019 \\
\hline Brunei & -328 & 392 & 14,210 & 7,136 & $-1,509$ & -405 \\
\hline Cambodia & 43,827 & 41,968 & 62,567 & 74,424 & 77,834 & 74,625 \\
\hline Indonesia & 127,198 & 145,057 & 146,088 & 168,225 & 186,482 & 222,308 \\
\hline Laos & 102,690 & 51,721 & 32,758 & 121,995 & 124,179 & 114,908 \\
\hline Malaysia & 52,134 & 48,891 & 182,996 & 172,214 & 166,270 & 110,954 \\
\hline Myanmar & 34,313 & 33,172 & 28,769 & 42,818 & $-19,724$ & $-4,194$ \\
\hline Philippines & 22,495 & $-2,759$ & 3,221 & 10,884 & 5,882 & -429 \\
\hline Singapore & 281,363 & $1,045,248$ & 317,186 & 631,990 & 641,126 & 482,567 \\
\hline Thailand & 83,946 & 40,724 & 112,169 & 105,759 & 73,729 & 137,191 \\
\hline Vietnam & 33,289 & 56,017 & 127,904 & 76,440 & 115,083 & 164,852 \\
\hline
\end{tabular}

The data comes from the «2019 China Foreign Investment Bulletin» of the Ministry of Commerce. A negative investment flow means that the original investment withdrawal or the host country's profit repatriation amount is greater than the current direct investment outflow amount. China Foreign Direct Investment Bulletin:http://hzs.mofcom.gov.cn/article/date/202009/20200903001523.shtml.Updated time:09/10/2020.

2014-2019 10 ASEAN Corruption Perceptions Index Ranking and China Direct Investment Flow Ranking

\begin{tabular}{|c|c|c|c|c|c|c|}
\hline Country/Year & 2014 & 2015 & 2016 & 2017 & 2018 & 2019 \\
\hline Brunei & $\mathrm{N} / 10$ & $\mathrm{~N} / 9$ & 28 & 210 & 210 & 8 \\
\hline Cambodia & 76 & 96 & 96 & 97 & 86 & 97 \\
\hline Indonesia & 42 & 42 & 43 & 43 & 42 & 42 \\
\hline Laos & 63 & $\begin{array}{ll}74 \\
\end{array}$ & 77 & 84 & 74 & 85 \\
\hline Malaysia & 25 & 25 & 32 & 32 & 33 & 36 \\
\hline Myanmar & 77 & 88 & 89 & 78 & 79 & $8 \quad 10$ \\
\hline Philippines & 39 & $\begin{array}{ll}5 & 10\end{array}$ & $\begin{array}{ll}5 & 10\end{array}$ & 69 & $\begin{array}{ll}58 \\
\end{array}$ & 79 \\
\hline Singapore & 11 & 11 & 11 & 11 & 11 & 1 \\
\hline Thailand & 34 & 37 & 55 & 45 & 57 & 4 \\
\hline Vietnam & 58 & 63 & 64 & 56 & 65 & 53 \\
\hline
\end{tabular}

Each country in the figure has two numbers. The first number is the ranking of the country's corruption index among the ten ASEAN countries, and the second number is the ranking of China's direct investment in the country among the ten ASEAN countries. Take the data of Cambodia in 2014 as an example, 7 is the ranking of Cambodia's corruption perception index, and 6 is the ranking of China's direct investment. 
From the above data, there is a clear conflict with the assertion that there is a significant negative correlation between the degree of corruption in the host country and external direct investment as judged by A. Based on the data on the Corruption Perceptions Index of the ten ASEAN Countries and China's Direct Investment Ranking, ASEAN countries can be divided into four categories: One is represented by Singapore. Its Corruption Perceptions Index ranking is consistent with China's Direct Investment Ranking and both rank first. Singapore complies with the foregoing assumption A; The second category is represented by Brunei, the Philippines, and Myanmar. China's direct investment ranking is lower than its ranking in the ASEAN countries' corruption index, that is, these countries have higher corruption index, but China's FDI is not high. Brunei is the most representative country. The situation of these three countries is in apparently conflict with the previous assumption A; The third category is represented by Indonesia, Laos, and Cambodia. China's direct investment ranking is higher than that of ASEAN countries. Corruption Perceptions Index rankings, that is, these countries are not high in the Corruption Perceptions Index, but China's investment in it is much higher than its rankings. Indonesia is the most representative country. The situation of these three countries apparently conflicts with the previous assumption A; The fourth category is Thailand, Malaysia, and Vietnam. The relationship between the ranking of the corruption index of these three countries and China's ranking of its direct investment is in an unstable state. In some years, the ranking of the corruption index is higher than that of China's direct investment. The Corruption Perception Index ranks in the ranking of China's direct investment. In general, the cases of the ten ASEAN countries show that only Singapore fully meets the assumption A, while the other 6 countries show a counterexample, that is, there is a positive correlation between the corruption level of the host country and external direct investment, and the cases of the other three countries also cannot verify. The preliminary results show that the strategic considerations of a country's foreign direct investment are diverse.

The Relationship Between the Institutional Distance of the ASEAN Countries and China's Foreign Direct Investment

With the development of economic globalization, various distance factors caused by national heterogeneity, especially the effect of institutional distance on OFDI, have attracted the attention of the academic community. Institutional distance is the degree of similarity or difference between two countries at the level of rules, norms, and cognition. It is a relative evaluation of the systems between countries and will have a special impact on the inflow of foreign capital from the host country ${ }^{1}$. This article uses the WGI indicator because it has many advantages such as higher rigor and comprehensiveness, and wider coverage. The global governance index includes Control of Corruption (CC), Government Effectiveness (GE), Political Stability and Absence of Violence/Terrorism (PV), Regulatory Quality(RQ), the level of the Rule of Law (RL), and Voice and Accountability (VA) six indicators. The scoring range of all indicators is $[-2.5,2.5]$, the average of the total scores of the six indicators is used to measure a country's overall system quality, the higher the value, the higher the system quality of

\footnotetext{
${ }^{1}$ Deng Ming. Institutional distance, demonstration effect and location distribution of OFDI in China // International trade issues. 2012. Vol. 2. Pp. 123-135.
} 
Sun Liping, Zheng Dongwen. A study on the Causes of International Anti-Corruption Cooperation between China and Southeast Asian Countries Under the Belt and Road Initiative

a country. The absolute value of the difference between the system quality of the two countries reflects the bilateral institutional distance.

Table 4

China and the ASEAN Countries' Global Governance Average Index (WGI Average Index)

\begin{tabular}{|c|c|c|c|c|c|c|}
\hline Country/Year & 2014 & 2015 & 2016 & 2017 & 2018 & 2019 \\
\hline Brunei & 1.57 & 1.59 & 1.61 & 1.62 & 1.64 & 1.63 \\
\hline Cambodia & 0.62 & 0.56 & 0.51 & 0.57 & 0.63 & 0.60 \\
\hline Indonesia & 0.48 & 0.38 & 0.32 & 0.28 & 0.48 & 0.43 \\
\hline Laos & -0.19 & -0.24 & -0.35 & -0.34 & -0.35 & -0.31 \\
\hline Malaysia & -0.22 & -0.29 & -0.18 & -0.17 & -0.15 & -0.17 \\
\hline Myanmar & -0.30 & -0.33 & -0.32 & -0.27 & -0.29 & -0.20 \\
\hline Philippines & -0.48 & -0.41 & -0.33 & -0.34 & -0.36 & -0.33 \\
\hline Singapore & -0.68 & -0.71 & -0.68 & -0.71 & -0.77 & -0.80 \\
\hline Thailand & -0.71 & -0.73 & -0.73 & -0.76 & -0.77 & -0.78 \\
\hline Vietnam & -1.19 & -1.15 & -0.83 & -0.89 & -0.93 & -0.95 \\
\hline China & -0.48 & -0.46 & -0.43 & -0.33 & -0.32 & -0.36 \\
\hline
\end{tabular}

The data comes from the World Bank WGI database. WGI Index: http://info.worldbank.org/governance/wgi/\#home, updated on August 11, 2020.

Table 5

The Scores of Institutional Distance Between the ASEAN Countries and China

\begin{tabular}{|c|c|c|c|c|c|c|}
\hline Country/Year & 2014 & 2015 & 2016 & 2017 & 2018 & 2019 \\
\hline Brunei & 2.05 & 2.03 & 2.04 & 1.95 & 1.96 & 1.99 \\
\hline Cambodia & 1.1 & 1.02 & 0.94 & 0.90 & 0.95 & 0.96 \\
\hline Indonesia & 0.96 & 0.84 & 0.75 & 0.61 & 0.8 & 0.79 \\
\hline Laos & 0.29 & 0.22 & 0.08 & 0.01 & 0.03 & 0.05 \\
\hline Malaysia & 0.26 & 0.17 & 0.25 & 0.16 & 0.17 & 0.19 \\
\hline Myanmar & 0.18 & 0.13 & 0.11 & 0.06 & 0.03 & 0.16 \\
\hline Philippines & 0 & 0.05 & 0.10 & 0.01 & 0.04 & 0.03 \\
\hline Singapore & 0.20 & 0.25 & 0.25 & 0.38 & 0.45 & 0.44 \\
\hline Thailand & 0.23 & 0.27 & 0.30 & 0.43 & 0.45 & 0.42 \\
\hline Vietnam & 0.71 & 0.69 & 0.40 & 0.56 & 0.61 & 0.59 \\
\hline
\end{tabular}

The basis comes from the World Bank WGI database. 
2014-2019 ASEAN System Distance Ranking and China Direct Investment Flow Ranking Icon

\begin{tabular}{|c|c|c|c|c|c|c|}
\hline Country/Year & 2014 & 2015 & 2016 & 2017 & 2018 & 2019 \\
\hline Brunei & 910 & 99 & 98 & 910 & 910 & 98 \\
\hline Cambodia & 46 & 66 & 56 & 67 & 56 & 57 \\
\hline Indonesia & 52 & 32 & 43 & 33 & 32 & 42 \\
\hline Laos & 33 & $\begin{array}{ll}54 \\
\end{array}$ & 47 & 54 & 54 & $\begin{array}{ll}6 & 5 \\
\end{array}$ \\
\hline Malaysia & 85 & 85 & 82 & 82 & 83 & 86 \\
\hline Myanmar & 77 & 78 & 79 & 78 & 79 & $7 \quad 10$ \\
\hline Philippines & 69 & 410 & 110 & 19 & 18 & 29 \\
\hline Singapore & $\begin{array}{ll}10 & 1\end{array}$ & 101 & 101 & 101 & 101 & 101 \\
\hline Thailand & 24 & 27 & 35 & 25 & 17 & 34 \\
\hline Vietnam & 18 & 13 & 24 & 16 & 25 & 13 \\
\hline
\end{tabular}

From the above data, there is a obvious conflict with the assertion that there is a significant negative correlation between the institutional distance of the host country and external direct investment as judged by B. Based on the data on the institutional distance of the ten ASEAN countries and the ranking of China's direct investment, ASEAN countries can be divided into three categories: One is Brunei, whose institutional distance is consistent with the ranking of China's direct investment and supports the judgment of B above; The second category These four countries are Singapore, Indonesia, Malaysia, and Laos. The institutional distance ranking of these four countries is higher than that of China's direct investment ranking, that is, the institutional distance between these countries and China is relatively large, but China's direct investment is very high. Singapore is a typical representative; The third category is the remaining five ASEAN countries. The institutional distance ranking of these five countries is lower than China's ranking of its direct investment. That is, these countries are relatively close to China's institutional distance, but China's direct investment is relatively low. Vietnam Is a typical representative. In general, only the Brunei case supports the previous assumption B, and the 9 cases of the second and third categories are in serious contradicted with the previous assumption B.

\section{Conclusion}

Based on the data and analysis in Table 1 to 6 , combining the domestic conditions of ASEAN countries and China's bilateral relations, the following points can be drawn:

First, there is no obvious negative correlation between China's direct foreign investment in the ten ASEAN countries along the Maritime Silk Road and the government quality and corruption control of these countries. Judging from the data on the corruption index, institutional distance, and China's direct foreign investment, there are few cases that meet the negative correlation conclusions, most of the cases are more complicated, and some cases show a positive correlation.

Secondly, the complex situation presented by the cases of the ten ASEAN countries shows that it is difficult to fully analyze the relationship between government quality and direct investment by a single variable such as the corruption index or institutional distance. It is necessary to introduce a comprehensive analysis of multiple fac- 
Sun Liping, Zheng Dongwen. A study on the Causes of International Anti-Corruption Cooperation between China and Southeast Asian Countries Under the Belt and Road Initiative

tors such as cultural distance, political stability, and bilateral relations. Take Singapore and Brunei as examples. Singapore and Brunei have high government quality and corruption index, and they have always ranked first and second among the ten ASEAN countries. However, China's direct investment in China presents a completely different situation. The Singaporean government has a high integrity index, good social security conditions, open and transparent enforcement of laws and regulations, and a Chinese population of more than $70 \%$. At present, China maintains a growth trend of OFDI in Singapore. This is in line with Singapore's local welcome to foreign capital and the efficiency of the local government (GE), integrity (CC), business law transparency (RQ), and many other aspects such as low political risk of investment and a better business environment are closely related. Singapore is one of the three largest offshore RMB clearing centers in the world and the largest foreign exchange trading center in Asia. Its outstanding financial service advantages in Asia can provide Chinese-funded enterprises with efficient and convenient financing mechanisms and channels.

Brunei has a relatively small land territory, a high degree of market openness, preferential taxation policies, a relatively stable political situation, relatively low comprehensive investment risks, and high transparency in related investment policies. However, the political and economic influence of Chinese in Brunei is less than that of Chinese in Indonesia, Malaysia, the Philippines, Singapore, and Thailand. The Brunei government pays more attention to supporting the development of Malays. It has designated certain industries that only the indigenous people of the country have the right to operate. The law stipulates that Brunei citizens can enjoy land ownership and the right to buy and sell, and foreigners can only rent it. Related policies restrict overseas Chinese intending to invest of foreign investment entities in the local economic activities. Therefore, the case studies of Singapore and Brunei show that the domestic political and cultural distance of the host country also affects China's foreign direct investment.

Third, unlike previous judgments, China's direct investment in some ASEAN countries has a significant positive correlation with its corruption index and institutional distance. Take Indonesia and Laos as examples, China's direct investment ranking is higher than its ranking in ASEAN countries' corruption index. That is, these countries' corruption index is not high, but China's investment is much higher than its ranking. Take the Philippines and Vietnam as examples, these two countries are very close to China's system, but China's direct investment is far below its system distance ranking. These cases illustrate the need to examine the strategic considerations of China's foreign direct investment, that is, China's investment in this type of country is often dominated by state-owned enterprises, and the pursuit of profit is not its only purpose, and resource seeking is not its only orientation. State-owned enterprises are making OFDI locations. When choosing, it should also take into account tasks such as expanding and consolidating diplomatic relations, and promoting economic growth in poor areas, and it is strongly supported by national policies.

Finally, combining the above three judgments and the advancement of China's «Belt and Road Initiative», especially affected by the Sino-US trade conflict, the funds available for China's foreign investment may be affected. China's overseas investment activities needs to shift from focusing on quantity to focusing on quality. It is necessary to comprehensively assess the corruption issues and government quality of ASEAN countries, increase international anti-corruption cooperation, and avoid the operational 
risks and negative impacts that corruption issues may bring to China's overseas direct investment. This article has three suggestions: First, strengthen the «Maritime Silk Road» construction corruption risk assessment and establish a risk control mechanism, especially strengthening the construction of an international anti-corruption pre-control cooperation mechanism. Although anti-corruption international cooperation has received the attention of ASEAN countries, and various countries have actively participated in the conclusion of relevant anti-corruption treaties and international cooperation. In fact, many treaties have not been fully and effectively put into practice. Many major projects in the construction of the «Maritime Silk Road» cost much capital expenditure, have a long construction period, and their rate of return is affected by many aspects, and there is often greater uncertainty. Therefore, it is necessary to strengthen the international cooperation of relevant departments and institutions and project-related projects. Corruption risk factors are evaluated and a risk control mechanism is established.

Second, China should provide more regional public products that are conducive to the sustainable development of economic and trade cooperation to countries along the «Maritime Silk Road», and gradually transform from a participant and passive enforcer of investment rules to a leader in rulemaking. Use investment and financing mechanisms such as the Asian Infrastructure Investment Bank to coordinate international investment activities, ensure open and transparent investment activities, and reduce the damage to China's national interests caused by negative political risks caused by the quality of the host country government.

Third, actively build an investment risk database based on big data, cloud computing, and other countries along the «Belt and Road», and related basic data analysis. China needs to establish a national risk database and a national risk early warning and assessment system centered on national risk basic theories, evaluation models and evaluation methods to help Chinese companies resist the impact of macro risks and systemic risks, and better manage and control major project investment risks. This provides a reference for the Chinese government and enterprises to predict the risks of ASEAN countries' policies and investment environment, and helps to enhance the effectiveness and confidence of Chinese investors' investment activities in the ASEAN region.

\section{References}

1. Deng Ming. Institutional distance, demonstration effect and location distribution of OFDI in China // International trade issues. 2012. Vol. 2. Pp. 123-135.

2. Habib M, Zurawicki L. Corruption and Foreign Direct Investment // Journal of International Business Studies. 2002. № 33(2). Pp. 291-307.

3. Kaufmann D. Aggregating governance indicators // Policy Research Working Paper. World Bank. 1999. № 2195. Pp. 1-39.

4. Li Xiao. East Asian miracle and «strong government» // Economic Science Press. 1997. Pp. 48-63.

5. Liu Xiaoguang, Yang Liankun. Bilateral political relations, institutional environment of host country and foreign direct investment // Financial Research. 2016. Vol. 12. Pp. 17-31.

6. Wang Yongqin, Du Julian, Wang Kai. Determinants of location choice of China's FDI: system, tax burden and resource endowment // Economic Research. 2014. Vol. 12. Pp. 126-142.

7. Zhang Qian, Li Fangfang, Cheng Baodong. Bilateral political relations, institutional environment of host country and location choice of OFDI in China // International Economic and trade exploration. 2019. Vol. 6. Pp. 89-103. 
Sun Liping, Zheng Dongwen. A study on the Causes of International Anti-Corruption Cooperation between China and Southeast Asian Countries Under the Belt and Road Initiative

The article was submitted 12.02.2021; approved after reviewing 26.04.2021; accepted for publication 18.05.2021.

\section{ИССЛЕДОВАНИЕ ПРИЧИН МЕЖДУНАРОДНОГО \\ АНТИКОРРУПЦИОННОГО СОТРУДНИЧЕСТВА \\ МЕЖДУ КИТАЕМ И СТРАНАМИ ЮГО-ВОСТОЧНОЙ АЗИИ \\ В РАМКАХ ИНИЦИАТИВЫ «ОДИН ПОЯС - ОДИН ПУТЬ»}

Сунь Липин

кандидат исторических наук, профессор,

Цзилиньский университет

КНР, 130012, г. Чаньчунь, ул. Цяньцзинь, 2699

sunlp@jlu.edu.cn

Чжэн Дунвэнь

магистр,

Цзилиньский университет

КНР, 130012, г. Чаньчунь, ул. Цяньцзинь, 2699

sunlp@jlu.edu.cn

Аннотация. В условиях постоянного расширения прямых иностранных инвестиций Китая в страны, расположенные вдоль «Морского шелкового пути», внешняя среда, с которой сталкиваются прямые иностранные инвестиции Китая, становится все более сложной. Влияние коррупции и качества государственного управления стало более заметным. За период с 2014 по 2019 г. индекс коррупции и институциональная дистанция оказывают влияние на прямые внешние инвестиции Китая в десять стран АСЕАН. Очевидной отрицательной корреляции по противодействию коррупции нет. Сложная ситуация в десяти странах АСЕАН показывает, что с помощью одной переменной, такой как индекс коррупции или институциональная дистанция, трудно полно проанализировать взаимосвязь между качеством государственного управления и прямыми инвестициями. Необходимо ввести комплексный анализ множества факторов, таких как культурная дистанция, политическая стабильность и двусторонние отношения. В связи с этим Китай должен усилить оценку коррупционных рисков строительства «Морского шелкового пути», создать механизм контроля рисков и предоставить больше региональных общественных продуктов, способствующих устойчивому развитию экономики и торгового сотрудничества между странами, расположенными вдоль «Морского шелкового пути».

Ключевые слова: индекс восприятия коррупции, институциональная дистанция, прямые иностранные инвестиции, инициатива «Один пояс - один путь».

\section{Для циитирования}

Сунь Липин, Чжэн Дунвэнь. Исследование причин международного антикоррупционного сотрудничества между Китаем и странами Юго-Восточной Азии в рамках инициативы «Один пояс - один путь» // Вестник Бурятского государственного университета. Гуманитарные исследования Внутренней Азии. 2021. Вып. 1. С. 25-35.

Статья поступила в редакцию 12.02.2021; одобрена после рецензирования 26.04.2021; принята к публикации 18.05.2021. 